\title{
Tingkat Kesiapan Kali PePe untuk Dikembangkan Sebagai KaWasan Wisata Berbasis Sungai di Kota SURAKarta
}

\author{
Nurul Widowati, Winny Astuti, Murtanti Jani Rahayu \\ Program Studi Perencanaan Wilayah Dan Kota \\ Fakultas Teknik \\ Universitas Sebelas Maret, Surakarta \\ Email: nurulwidowati17@gmail.com
}

\begin{abstract}
Surakarta is a city that has the potential of the river. But in the process, these rivers suffered environmental degradation as a function instead of the banks into slums and squatter, and functions of rivers that serve as places of waste disposal. Government's city of Surakarta has done various setup area of the river. One of the targeted structuring Pepe-River is often known by the name Kali Pepe. Kali Pepe is the river which has the most strategic location because it divides the centre of city and the river has a past history of Surakarta. Kali Pepe is the witness of history where culture and trade activities in the rapidly growing city of Surakarta in the past with the ecological function and physical function as transportation trade.Setuping Kali Pepe, according to the Mayor of Surakarta, is directed to serve as recreation/tourism area. Since the Surakarta Mayor initiated the year 2015 that Kali Pepe as a tourist area. The initiated moves the government and society in order to more actively participate in developing the area into a tourist area. This research would like to know how the readiness level of the Kali Pepe area to be developed as a tourist area-based streams. The components of preparedness were seen from aspect of attractions or natural tourist attraction, artificial attractions, acessesiblity, institutional, infrastructure supporting tourism, and the behavior of the flooding of the river. This research is quantitative research in methods of scoring analysis. The result of this research has shown that Kali Pepe less readiness to be developed as a tourist area-based stream. Aspects of accessibility and infrastructure supporting tourism were an aspect which has a readiness. But for this aspect of the attraction, institutional and river flooding behavior is still in the stage of less readiness.
\end{abstract}

Keywords: readiness, tourist areas, river tours

\section{PENDAHULUAN}

Wisata adalah kegiatan perjalanan yang dilakukan oleh seseorang atau sekelompok orang dengan mengunjungi tempat tertentu untuk tujuan rekreasi, pengembangan pribadi, atau mempelajari keunikan daya tarik wisata yang dikunjungi dalam jangka waktu sementara (Undang-Undang No. 10 Tahun 2009 tentang Kepariwisataan). Seiring dengan perkembangannya kebutuhan akan wisata semakin mengalami peningkatan. Hal ini mendorong semakin berkembangnya sektor pariwisata di suatu wilayah.

Sektor pariwisata merupakan salah sektor penggerak perekonomian wilayah. Sektor tersebut dapat berperan dalam menambah sumber pendapatan asli daerah. Pitana dan Diarta (2009) menyatakan bahwa dalam kehidupan modern, sektor pariwisata telah menjadi salah satu kekuatan sosial dan ekonomi yang penting bagi suatu wilayah. Sektor pariwisata berkembang sesuai dengan ketersediaan potensi wisata serta daya tarik wisata yang dimiliki suatu daerah.

Salah satu daya tarik wisata yaitu wisata berbasis sungai. Wisata sungai umumnya dikembangkan dengan daya tarik alam berupa keindahan panorama, kejernihan air dan kedahsyatan arus (Sunaryo, 2013). Sungai di pedesaan cenderung dikembangkan untuk kegiatan-kegiatan wisata alam seperti arum jeram. Sedangkan di perkotaan dikembangkan untuk menikmati suasana perkotaan.

Dalam perkembangannya sungai di perkotaan cenderung berkembang kearah kawasan kumuh. Sungai di perkotaan cenderung memiliki kesan yang kotor dan bau karena sebagai tempat pembuangan limbah. Namun hal ini tak menutup kemungkinan jika sungai di perkotaan juga dapat dikembangkan menjadi wisata sungai. Hal ini terbukti dengan adanya berbagai kota di dunia yang telah mengembangkan sungai sebagai salah satu destinasi wisata di antaranya adalah New 
York, Seoul dan Singapura melalui integrasi antara daya tarik alam, daya tarik budaya dan daya tarik minat khusus.

Kota Surakarta merupakan salah satu kota yang memiliki potensi berbagai sungai. Kota Surakarta dilewati oleh 3 sungai besar yaitu Sungai Bengawan Solo, Sungai Pepe serta Sungai Anyar. Selain itu masih terdapat beberapa anak sungai lainnya. Hal itu yang menjadikan Kota Surakarta juga dikenal sebagai Kota Bengawan. Dalam perkembangannya sungai-sungai di Kota Surakarta mengalami degradasi lingkungan di antaranya karena alih fungsi bantaran menjadi pemukiman liar dan menjadi tempat pembuangan limbah. Berbagai upaya dari pemerintah telah dilakukan untuk mengatasi hal tersebut.

Salah satu sungai yang sedang giat dilakukan penataan saat ini yaitu Sungai Pepe atau sering dikenal dengan Kali Pepe. Kali Pepe memiliki lokasi yang paling strategis yaitu membelah pusat Kota Surakarta. Kali Pepe merupakan sungai yang menjadi saksi sejarah dimana kebudayaan dan kegiatan perdagangan di Kota Surakarta berkembang pesat di masa lampau dengan fungsi ekologis serta fungsi fisiknya sebagai jalur transportasi perdagangan.

Penataan Kali Pepe menurut walikota Surakarta diarahkan untuk dijadikan sebagai kawasan rekreasi / wisata. Sejak tahun 2015 walikota Surakarta meresmikan bahwa Kali Pepe sebagai kawasan wisata. Peresmian tersebut untuk menggerakkan pemerintah dan masyarakat agar lebih giat berpartisipasi dalam mengembangkan kawasan tersebut menjadi kawasan wisata. Pengembangan Kali Pepe untuk wisata tersebut diharapkan juga dapat meningkatkan perekonomian masyarakat sekitar sungai tersebut.

Kebijakan penataan Kali Pepe yang mengarahkan sebagai kawasan wisata termuat dalam beberapa dokumen pemerintah di antaranya dalam dokumen "Penataan Sempadan Sungai Bengawan Solo tahun 2012 studi kasus Kali Pepe dan Kali Anyar". Dalam dokumen tersebut disebutkan bahwa salah satu bentuk pengembangan Kali Pepe dalam bidang ekonomi yaitu penataan bantaran sebagai kawasan rekreasi/wisata. Selain itu juga termuat dalam dokumen "Penataan Kawasan Anak Sungai Bengawan Solo tahun 2014". Salah satu konsep penanganan Kali Pepe dalam dokumen tersebut yaitu penataan kawasan wisata.
Pada dasarnya sebelum memutuskan pemanfaatan suatu perairan untuk pengembangan kepariwisataan perlu dipertimbangkan berbagai faktor (Fandeli, 1995). Oleh karena itu pengembangan Kali Pepe untuk dijadikan kawasan wisata perlu melihat aspek-aspek pengembangan wisata lainnya. Penelitian ini ingin mengetahui tingkat kesiapan Kawasan Kali Pepe untuk dikembangkan sebagai kawasan wisata berbasis sungai di Kota Surakarta.

\section{TINJAUAN PUSTAKA}

Kesiapan merupakan suatu kondisi untuk mengukur atau menilai kematangan dari sebuah kawasan. Kesiapan kawasan untuk dikembangkan menjadi suatu kawasan wisata diartikan sebagai indikator yang menunjukkan seberapa siap atau matang suatu kawasan untuk bisa dijadikan sebagai objek wisata dilihat dari komponen pariwisata.

Kawasan pariwisata adalah kawasan dengan luas tertentu yang dibangun atau disediakan untuk memenuhi kebutuhan pariwisata (UU Nomor 10 Tahun 2009 tentang Kepariwisatawan). Berdasarkan UndangUndang tersebut dijelaskan bahwa pengertian kawasan wisata adalah suatu kawasan yang mempunyai luas tertentu yang dibangun dan disediakan untuk kegiatan pariwisata. Wisata sungai adalah kegiatan wisata yang objek dan daya tariknya bersumber dari potensi sungai. Dapat disimpulkan bahwa kawasan wisata sungai merupakan kawasan yang dibangun atau disediakan untuk kegiatan wisata dengan obyek dan daya tariknya berasal dari potensi sungai.

Wisata sungai umumnya dikembangkan dengan daya tarik alam berupa keindahan panorama, kejernihan air dan kedahsyatan arus (Sunaryo, 2013). Selain itu, Fandeli (2009) menegaskan bahwa lingkungan perairan merupakan suatu ekosistem yang memiliki sifat dan kekayaan alam yang melimpah. Pada bagian atau segmen sungai di wilayah kota yang masih relatif alami atau yang memiliki pemandangan alam yang indah dapat ditetapkan sebagai resort wisata (Fandeli, 2009).

Pemandangan alam ditetapkan ke dalam 4 lingkungan (Gunn dalam Fandeli, 2009):

1. Area yang terdapat lanskap yang bagus dapat dipergunakan untuk wisata berjalan santai di tepi sungai. Di area tepi sungai ini tidak ada bangunan, yang ada hanya fasilitas tempat duduk. 
2. Area di tepi sungai yang dirancang ada berbagai bangunan, hotel dan permukiman rendah, diantara bangunan ini dibangun landscaping yang bagus.

3. Area di tepi sungai yang dipergunakan sebagai area intensif dengan landscape ditata toko, restoran, hotel dan tempat pertunjukan

4. Area di tepi sungai dirancang untuk lingkungan binaan. Lingkungan binaan ini untuk steater, gedung pertunjukan dan lain-lain.

Salah satu hal penting dalam penelitian sebelum merancang sungai sebagai wisata yaitu mempertimbangkan perilaku banjir. Disamping itu faktor lokasi, transportasi dan harga tanah sebagai faktor pendukung yang patut diperhatikan (Fandeli, 2009)

Terdapat enam elemen utama pembentuk daya tarik wisata dalam pengembangan pariwisata yang termasuk pariwisata air sungai yaitu (Robinson dalam Yuliarsi,2005):

1. Cuaca, merupakan ciri khusus pada pariwisata yang menyebabkan suatu lokasi menjadi potensial bagi pariwisata.

2. Pemandangan, atraksi berupa pemandangan menarik.

3. Fasilitas, terdiri dari dua jenis yaitu alam dan buatan.

4. Sejarah dan budaya, peninggalan sejarah atau seni budaya suatu daerah.

5. Aksesibilitas, semakin mudah mencapai lokasi wisata maka semakin tinggi pula kemungkinan untuk dikunjungi.

6. Akomodasi, menyangkut tempat penginapan dan tempat makan

7. Kelembagaan

\section{METODE PENELITIAN}

Pendekatan penelitian yang digunakan dalam penelitian mengenai kajian tingkat kesiapan Kawasan Kali Pepe Kota Surakarta untuk dikembangkan sebagai kawasan wisata berbasis sungai yaitu bersifat deduktif atau umum khusus. Pendekatan deduktif merupakan pendekatan penelitian yang dilakukan dengan meguji teori. Hipotesis atau pertanyaan penelitian dan variabel dalam pendekatan deduktif diturunkan dari teori (Creswell, 2010).

\subsection{Ruang Lingkup}

Ruang lingkup wilayah dalam penelitian yaitu sebagian Kali Pepe Hilir Kota Surakarta. Secara administrasi ruang lingkup tersebut yaitu Kali Pepe yang berada di Kelurahan Setabelan, Kelurahan Keprabon, Kelurahan
Kepatihan Kulon, Kelurahan Kampung Baru, Kelurahan Ketelan, Kelurahan Kestalan, Kelurahan Kepatihan Wetan, Kelurahan Sudiroprajan dan Kelurahan Kedunglumbu.

\subsection{Variabel Penelitian}

Variabel dalam penelitian ini didapatkan dari kajian teori berupa teori komponen pariwisata secara umum dan teori pengembangan kawasan wisata sungai kemudian dikaitkan dengan teori kesiapan. Adapun variabel dan indikatornya dapat dilihat pada Lampiran.

\subsection{Data Penelitian}

Data yang digunakan dalam penelitian ini meliputi data sekunder yang didapatkan dari institusi pemerintahan dan data primer yang didapatkan dari kegiatan verifikasi lapangan. Adapun kebutuhan data penelitian dapat dilihat pada Tabel 1.

\subsection{Metode Analisis Penelitian}

Teknik analisis data yang digunakan pada penelitian ini adalah teknik analisis skoring. Data yang terdapat pada penelitian ini merupakan data nominal yang bersifat kualitatif, yang kemudian diubah menjadi data kuantitatif dengan cara pemberian skor (skoring). Untuk mendapatkan temuan dilakukan dengan cara membandingkan hasil skoring dengan teori dan kondisi-kondisi yang ada di Kali Pepe Kota Surakarta. Teknik analisis yang dilakukan antara lain :

1. Analisis skoring kesiapan dari tiap aspek/variabel.

2. Analisis skoring kesiapan Kawasan Kali Pepe.

Tabel 1. Kebutuhan Data Penelitian

\begin{tabular}{|c|c|}
\hline Kebutuhan Data & $\begin{array}{l}\text { Teknik } \\
\text { Pengumpulan }\end{array}$ \\
\hline $\begin{array}{l}\text { - Kondisi eksisting penggunaan } \\
\text { lahan ditepi sungai } \\
\text { - Sebaran pemandangan tepi sungai }\end{array}$ & Observasi \\
\hline $\begin{array}{l}\text { - Kuantitas air sungai } \\
\text { - Kualitas air sungai }\end{array}$ & Studi Dokumen \\
\hline Debit air sungai & Studi Dokumen \\
\hline $\begin{array}{l}\text { - Jenis atraksi buatan yang dapat } \\
\text { dikembangkan dikawasan } \\
\text { - Keberadaan fasilitas/sistem untuk } \\
\text { mendukung atraksi }\end{array}$ & $\begin{array}{l}\text { - Observasi } \\
\text { Lapangan } \\
\text { - Wawancara } \\
\text { - Studi dokumen }\end{array}$ \\
\hline $\begin{array}{l}\text { - Jaringan transportasi umum } \\
\text { menuju kawasan dan sebaliknya } \\
\text { - Keberadaan moda menuju } \\
\text { kawasan dan sebaliknya }\end{array}$ & Studi Dokumen \\
\hline $\begin{array}{llll}\begin{array}{l}\text { Keberadaan } \\
\text { pejalan kaki }\end{array} & \text { akses jalan untuk } \\
\end{array}$ & Observasi \\
\hline $\begin{array}{l}\text { - Dokumen kebijakan perencanaan } \\
\text { kawasan } \\
\text { - Dokumen laporan pembangunan }\end{array}$ & $\begin{array}{l}\text { - Studi Dokumen } \\
\text { - Wawancara }\end{array}$ \\
\hline
\end{tabular}




\begin{tabular}{|l|l|}
\hline Kebutuhan Data & $\begin{array}{l}\text { Teknik } \\
\text { Pengumpulan }\end{array}$ \\
\hline $\begin{array}{l}\text { yang telah dilaksanakan } \\
\text { dikawasan } \\
\text { - Peran lembaga terkait }\end{array}$ & \\
\hline $\begin{array}{l}\text { Bentuk peran masyarakat dalam } \\
\text { mengelola sungai secara } \\
\text { perorangan dalam }\end{array}$ & Kuesioner \\
\hline $\begin{array}{l}\text { Bentuk peran masyarakat studi Dokumen } \\
\text { mengelola sungai } \\
\text { forum/lembaga }\end{array}$ & - Wawancara \\
\hline $\begin{array}{l}\text { Sebaran fasilitas rumah makan dan } \\
\text { wisata belanja }\end{array}$ & Observasi \\
\hline Sebaran fasilitas Bank dan ATM & Observasi \\
\hline Sebaran fasilitas akomodasi & Observasi \\
\hline $\begin{array}{l}\text { Keberadaan Jaringan listrik } \\
\text { kawasan }\end{array}$ & - Observasi \\
\hline $\begin{array}{l}\text { Keberadaan jaringan air bersih } \\
\text { Keberadaan jaringan komunikasi }\end{array}$ & $\begin{array}{l}\text { - Observasi } \\
\text { - Wawancara }\end{array}$ \\
\hline $\begin{array}{l}\text { Data } \\
\text { banjir/genangan }\end{array}$ & $\begin{array}{l}\text { - Studi Dokumen } \\
\text { - Wawancara }\end{array}$ \\
\hline
\end{tabular}

\section{HASIL DAN PEMBAHASAN}

\subsection{Tingkat Kesiapan Atraksi/Daya Tarik Alam Wisata Sungai}

Tingkat kesiapan atraksi alam diukur dari keberadaan daya tarik pemandangan alam lanskap tepi sungai, air sungai serta arus sungai untuk kegiatan wisata.

Keberadaan pemandangan pada lanskap tepi Kali Pepe termasuk dalam kategori kurang siap. Menurut Fandeli (2009) pada segmen sungai di wilayah kota yang masih relatif alami atau memiliki pemandangan alam yang indah dapat ditetapkan sebagai resort wisata. Beberapa segmen Kali Pepe pada kawasan studi telah memiliki pemandangan pada lanskap tepi sungai seperti taman, situs budaya, pemukiman yang ditata menjadi rumah deret serta pedestrian yang dilengkapi berbagai fasilitas seperti tempat duduk dan penerangan jalan. Namun kondisi tepi Kali Pepe tersebut belum seluruhnya memiliki pemandangan yang menjadi daya tarik. Beberapa segmen pada Kali Pepe masih memiliki kondisi tepi sungai berupa bangunan liar.

Aspek lain dari kesiapan daya tarik dilihat dari keberadaan air. Menurut Fandeli (2009) untuk mengembangkan suatu sungai untuk pariwisata pertimbangan keberadaan air sungai sangat penting. Keberadaan air Kali Pepe secara kuantitas dalam kategori kurang siap. Kali Pepe termasuk sebagai sungai periodik yang memiliki keberadaan air yang besar hanya pada musim hujan. Pegembangan kawasan wisata dengan kegiatan wisata seperti wisata perahu membutuhkan air yang cukup banyak sehingga perlu adanya penanganan khusus untuk ketersediaan air tersebut.

Menurut PP No 82 tahun 2001, kualitas air sungai yang dapat digunakan sebagai sarana wisata air yaitu minimal kelas II. Kualitas air Kali Pepe termasuk dalam kualitas air tercemar golongan IV yang mengandung COD dan BOD yang cukup tinggi. Kandungan air tersebut disebabkan dari hasil limbah domestik yang langsung dibuang ke sungai. Dengan demikian, secara kualitas air Kali Pepe dalam kategori tidak siap untuk dikembangkan wisata.

Selanjutnya kesiapan daya tarik lainnya yaitu keberadaan arus sungai. Salah satu pengembangan wisata pada Kali Pepe yaitu kegiatan wisata perahu. Menurut Fandeli (2009) untuk mampu membuat produk wisata berbasis sungai, maka perlu memahami perilaku arus sungai agar berbagai bentuk kegiatan wisata berbasis sungai seperti canoeing atau rafting dapat kiranya dijalankan secara maksimal. Menurut analisis HEC-RAS yang dilakukan oleh Balai Besar Wilayah Sungai (BBWS) Bengawan Solo Kota Surakarta, kegiatan wisata perahu dapat dilaksanakan dengan adanya debit sungai minimal 6m3/detik. Keberadaan debit Kali Pepe hanya ada pada bulan Februari, Maret dan April sehingga kegiatan wisata tersebut tidak dapat dijalankan secara maksimal setiap waktu. Dapat disimpulkan bahwa keberadaan arus pada Kali Pepe juga termasuk dalam kategori kurang siap.

\subsection{Tingkat Kesiapan Atraksi/Daya Tarik Buatan}

Tingkat kesiapan atraksi penunjang diukur dari ketersediaan atraksi penunjang wisata yang dapat dikembangkan. Terdapat beberapa jenis atraksi penunjang wisata sungai yaitu santai tepi perairan, wisata keliling perairan serta olahraga perairan. Kegiatan wisata santai tepi Sungai Kali Pepe dapat dilakukan pada tiga dari enam segmen yang ada yaitu pada segmen 1, 4 dan 6. Pada segmen tersebut sudah dilakukan penataan bantaran dengan pemberian fasilitas berupa tempat duduk. Wisata keliling sungai dengan perahu, baru dikembangkan pada satu segmen yaitu segmen 6 yang diselenggarakan untuk memeriahkan acara Grebeg Sudiro. Kegiatan olahraga air belum dapat dikembangkan pada Kali Pepe karena kondisi air yang belum memungkinkan. 
Robinson (1976 dalam Yuliarsi 2005) menambahkan bahwa peninggalan sejarah atau seni budaya merupakan salah satu elemen pembentuk daya tarik wisata dalam pengembangan wisata termasuk wisata air sungai. Pada Kawasan Kali Pepe terdapat beberapa kegiatan kebudayaan yang diselenggarakan di kawasan tersebut seperti kirab pada Grebeg Sudiro yang dilakukan dengan berperahu dan Kirab Hanguri-Uri budaya kamar mandi umum yaitu kirab situs bersejarah yang letaknya berada di tepi Kali Pepe. Selain itu, di sekitar Kawasan Kali Pepe juga terdapat beberapa bangunan bersejarah seperti Keraton Mangkunegaran, Benteng Vasterberg, Pasar Gede serta Pasar Legi yang bisa menjadi destinasi penunjang wisata.

Atraksi penunjang pada Kawasan Kali Pepe sudah cukup beragam namun dalam pengembangannya belum merata diseluruh segmen. Rata-rata pengembangan atraksi penunjang wisata tersebut yaitu $29,16 \%$. Angka tersebut dalam range kesiapan termasuk dalam kategori tidak siap. Atraksi penunjang wisata Kali Pepe belum dapat dikembangkan secara maksimal karena kondisi sungai maupun bantaran sungai yang masih banyak mengalami permasalahan.

\subsection{Tingkat Kesiapan Aksesibilitas}

Tingkat kesiapan aksesibilitas diukur dari kemudahan kawasan diakses dengan transportasi umum serta kemudahan akses pejalan kaki pada kawasan. Kawasan Kali Pepe pada wilayah studi dapat dijangkau dengan menggunakan transportasi umum Kota Surakarta. Jenis transportasi umum di Kota Surakarta yang menjangkau kawasan studi yaitu berupa bus dan angkutan umum (angkot). Beberapa transportasi umum dengan segenap fasilitas dan moda angkutan akan memudahkan serta membuat nyaman wisatawan untuk mengunjungi suatu destinasi (Sunaryo, 2013). Pada setiap segmen Kali Pepe terdapat jaringan transportasi umum baik berupa bus kota seperti BST, Damri Nusa, SKA Jaya, Surya Kencana, Atmo maupun angkutan umum . Secara umum keberadaan Kawasan Kali Pepe memiliki kemudahan untuk diakses dengan menggunakan transportasi umum. Hal ini juga didukung dari lokasi kawasan yang berada pada lokasi yang strategis yaitu melalui pusat pemerintahan serta perdagangan dan jasa Kota Surakarta. Dengan demikian, Kawasan Kali Pepe memiliki kesiapan aksesibilitas dengan transportasi umum.

Akses pejalan kaki pada kawasan dilihat dari keberadaan ruang untuk berjalan kaki pada kawasan. Pada Kawasan Kali Pepe segmen 1, 4 dan 6 sudah memiliki ruang pedestrian untuk pejalan kaki dengan lebar 2-3 meter. Pada segmen 3 masih dalam proses pembangunan. Segmen 2 dan 5 belum memiliki akses pejalan kaki dimana masih terdapat bangunan-bangunan baik permukiman maupun perdagangan dan jasa. Dalam range kesiapan akses pejalan kaki termasuk dalam kategori kurang siap. Prosentase kemudahan akses pejalan kaki yaitu 50\% dimana masih terdapat beberapa segmen yang tidak dapat diakses dengan berjalan kaki.

\subsection{Tingkat Kesiapan Kelembagaan}

Tingkat kesiapan kelembagaan pada Kawasan Kali Pepe dilihat dari peran pemerintah dan peran masyarakat dalam mengelola kawasan tersebut.

Menurut PP No. 38 tahun 2011 tentang sungai, pengelolaan sungai oleh pemerintah seharusnya dilakukan melalui beberapa tahap yaitu penyusunan program dan kegiatan, pelaksanaan kegiatan serta pemantauan atau evaluasi. Dalam pengelolaannya pemerintah hanya menyusun beberapa dokumen kebijakan dan melaksanakan program-program. Sementara untuk bentuk pemantauan atau evaluasi dari pembangunan yang dilaksanakan, tindakan yang dilakukan oleh stakeholder berupa evaluasi dari SKPD pada akhir tahun dalam rangka penyusunan laporan pertanggungjawaban rencana kerja. Tindakan pengawasan langsung pada kawasan tidak dilakukan oleh lembaga terkait. Hal ini dapat dilihat dari beberapa kasus misalnya bantaran sungai yang sudah ditata dan dibangun pedestrian dan fasilitas tempat duduk justru digunakan untuk lahan parkir dan tempat menjemur pakaian sehingga fasilitas tersebut justru mengalami kerusakan. Pemerintah harus lebih meningkatkan perannya terutama dalam pemantauan ke lapangan sehingga bisa lebih tegas memberikan peraturan.

Dalam PP No. 37 Tahun 2012 tentang pengelolaan daerah aliran sungai menyebutkan bahwa peran masyarakat secara perorangan berupa menjaga, memelihara serta menikmati lingkungan sungai. Masyarakat menikmati lingkungan sungai dengan mayoritas setuju bahwa Kali Pepe dikembangkan menjadi 
kawasan wisata. Namun terkait peran menjaga dan memelihara masih memiliki peran yang rendah. Beberapa masyarakat masih membuang sampah ke sungai. Selain itu, terkait memelihara sungai dilihat dari kebiasaan masyarakat membersihkan lingkungan sungai yaitu mayoritas masyarakat tidak permah membersihkan sungai. Mereka berpendapat bahwa kegiatan tersebut merupakan tugas dari pemerintah.

Peran masyarakat secara forum berdasarkan data yang diperoleh yaitu berupa peran menampung aspirasi masyarakat serta memberikan sumbangan pemikiran ke pemerintah. Dalam peraturan pemerintah No. 37 Tahun 2012 tentang pengelolaan daerah aliran sungai, forum koordinasi mempunyai fungsi untuk menampung dan menyalurkan aspirasi masyarakat terkait pengelolaan daerah aliran sungai; memberikan sumbangan pemikiran dalam pengelolaan daerah aliran sungai; dan mengembangkan peran pengawasan masyarakat dalam pengelolaan daerah aliran sungai. Dilihat dari peranannya, komunitas peduli Kali Pepe ini sudah melaksanakan peran terkait menampung aspirasi masyarakat dari kegiatan sosialisasi masyarakat dan pertemuan lintas kelurahan. Terkait peran dalam memberikan sumbangan pemikiran dilakukan dengan diskusi dengan berbagai pihak seperti Balai Besar Wilayah Sungai (BBWS) Bengawan Solo, Dinas Pekerjaan Umum (DPU), Walikota dan beberapa perguruan tinggi. Namun terkait peran untuk melakukan pengawasan ke masyarakat belum dilakukan oleh komunitas tersebut.

\subsection{Tingkat Kesiapan Sarana Prasarana Pendukung Wisata}

Tingkat kesiapan sarana prasarana pendukung wisata dilihat dari ketersediaannya dan keterjangkauannya. Sarana pendukung wisata berupa sarana perdagangan, sarana pelayanan keuangan serta sarana akomodasi/ penginapan. Sedangkan prasarana berupa jaringan listrik, air bersih dan jaringan komunikasi.

Sarana perdagangan untuk mendukung wisata yaitu sarana rumah makan dan wisata belanja. Menurut SNI dijelaskan bahwa radius pencapaian maksimal sarana perdagangan yaitu 300 meter. Ketersediaan sarana perdagangan berupa rumah makan dan wisata belanja pada Kawasan Kali Pepe sudah cukup banyak dan keberadaannya terjangkau dengan jarak <300m. Sedangkan untuk sarana pelayanan keuangan dan akomodasi tidak ada standar jangkauan pelayanannya sehingga menggunakan standar kemampuan orang berjalan kaki yaitu 400 meter (Peraturan Menteri Pekerjaan Umum tentang Pedoman Perencanaan, Penyediaan, dan Pemanfaatan Prasarana dan Sarana Jaringan Pejalan Kaki di Kawasan Perkotaan tahun 2014). Sarana pelayanan keuangan pada Kawasan Kali Pepe berupa Bank dan ATM sedangkan sarana akomodasi berupa hotel dan homestay. Keberadaan sarana tersebut berada pada jangkauan kurang dari 400 meter.

Selain sarana, keberadaan prasarana pendukung wisata seperti air bersih, listrik maupun telekomunikasi juga harus disediakan. Kawasan Kali Pepe menurut wawancara dari masyarakat sekitar Kali Pepe sudah terlayani oleh jaringan air bersih, listrik, maupun telekomunikasi. Sumber air bersih berasal dari Perusahaan Daerah Air Minum (PDAM) dan sumur. Sebagian masyarakat menggunakan air bersih dari sumur. Di sekitar Kali Pepe banyak ditemukan kamar mandi umum yang mana airnya bersumber dari sumur tanah. Adanya jaringan dari semua jenis operator membuktikan pada kawasan telah terlayani jaringan telekomunkasi yang dapat memudahkan wisatawan nantinya berkomunikasi. Dengan demikian untuk prasarana pendukung wisata termasuk dalam kategori siap.

\subsection{Tingkat Kesiapan Perilaku Banjir Sungai}

Tingkat kesiapan perilaku banjir kawasan sungai diukur dari tingkat kerawanan kawasan terhadap bencana banjir maupun genangan. Berdasarkan hasil analisis presentase kawasan rawan genangan pada Kawasan Kali Pepe yaitu $50 \%$.

Menurut Fandeli (2009) salah satu hal penting sebelum merancang sungai sebagai wisata yaitu mempertimbangkan perilaku banjir. Kawasan sungai yang dikembangkan menjadi wisata seharusnya bebas dari bahaya banjir maupun genangan.

Sementara itu, Kawasan Kali Pepe masih terdapat kawasan yang rawan terhadap genangan terutama saat musim hujan. Hal ini terjadi akibat kapasitas aliran Kali pepe Hilir yang tidak bisa menampung air yang masuk. Selain itu diakibatkan karena banyaknya sampah dan sedimentasi di kawasan tersebut. Genangan yang berada dekat dengan Sungai 
Bengawan Solo terjadi akibat dari luapan sungai Bengawan Solo yang masuk ke Kali Pepe. Pintu air Demangan yang berfungsi menjaga aliran dari Bengawan Solo tidak mampu menahan arus air sehingga air masuk ke Kali Pepe. Kawasan Kali Pepe perlu adanya penanganan terhadap banjir atau genangan yang terjadi pada Kali Pepe seperti penanganan pada sedimentasi, sampah serta perbaikan pintu air pengendali banjir.

\subsection{Tingkat Kesiapan Kawasan Kali Pepe Untuk Dikembangkan sebagai Kawasan Wisata Berbasis Sungai}

Tingkat kesiapan Kawasan Kali Pepe untuk dikembangkan sebagai kawasan wisata berbasis sungai diukur dengan melihat hasil analisis masing-masing komponen atau variabel. Berikut ini penilaian kesiapan Kawasan Kali Pepe untuk dikembangkan sebagai kawasan wisata. Adapun hasil skoring kesiapan Kawasan Kali Pepe dapat dilihat pada Tabel 2.

Tabel 2. Skoring Kesiapan Kawasan

\begin{tabular}{|c|c|c|c|}
\hline $\begin{array}{l}\mathrm{N} \\
\mathrm{o}\end{array}$ & Variabel & Hasil Skor & Kategori \\
\hline 1 & $\begin{array}{l}\text { Atraksi alam } \\
\text { wisatasungai }\end{array}$ & 0,35 & $\begin{array}{l}\text { Kurang } \\
\text { Siap }\end{array}$ \\
\hline 2 & $\begin{array}{l}\text { Atraksi buatan } \\
\text { wisata sungai }\end{array}$ & 0,20 & Tidak Siap \\
\hline 3 & Aksesibilitas & 0,37 & Siap \\
\hline 4 & Kelembagaan & 0,30 & $\begin{array}{l}\text { Kurang } \\
\text { Siap }\end{array}$ \\
\hline 5 & $\begin{array}{l}\text { Sarana } \\
\text { prasarana }\end{array}$ & 0,45 & Siap \\
\hline 6 & $\begin{array}{l}\text { Perilaku banjir } \\
\text { sungai }\end{array}$ & 0,30 & $\begin{array}{l}\text { Kurang } \\
\text { Siap }\end{array}$ \\
\hline \multicolumn{2}{|c|}{ Total Skor } & \multicolumn{2}{|c|}{ 1,97 (Kurang Siap) } \\
\hline
\end{tabular}

Tingkat kesiapan Kawasan Kali Pepe untuk dikembangkan sebagai kawasan wisata berbasis sungai di Kota Surakarta dari hasil skoring yaitu 1,97. Nilai tersebut menurut interval yang telah ditentukan yaitu termasuk dalam kategori kurang siap. Hal ini berarti Kawasan Kali Pepe untuk menjadi kawasan yang siap dikembangkan sebagai kawasan wisata perlu diperbaiki atau ditingkatkan beberapa komponen pengembangan wisata lainnya.

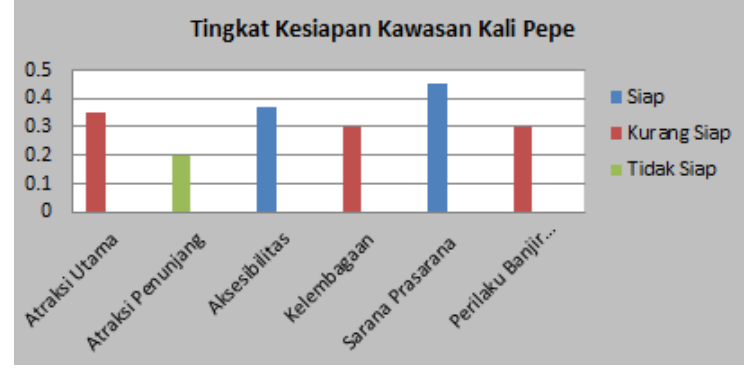

Gambar 1. Grafik Kesiapan Tiap Variabel

Pada grafik (lihat Gambar) dapat diketahui bahwa aspek sarana prasarana pendukung wisata memiliki kesiapan paling tinggi. Sedangkan aspek atraksi penunjang merupakan aspek yang paling tidak siap dalam pengembangan Kawasan Kali Pepe untuk dikembangkan sebagai kawasan wisata.

\section{KESIMPULAN}

Hasil analisis mengenai komponen pengembangan wisata pada Kawasan Kali Pepe menunjukkan bahwa Kawasan Kali Pepe kurang siap untuk dikembangkan sebagai kawasan wisata. Meskipun dari segi aksesibilitas dan sarana prasarana pendukung wisata sudah dalam kondisi siap namun masing terdapat komponen yang kurang siap. Komponen yang belum/kurang siap di antaranya atraksi/daya tarik baik alam maupun buatan, kelembagaan serta perilaku banjir kawasan sungai. Kawasan Kali Pepe perlu diperbaiki komponen-komponen pengembangan wisata untuk menjadi kawasan yang siap sebagai kawasan wisata.

\section{REFERENSI}

Creswell, John. 2010. Research Design Pendekatan Kualitatif, kuantitatif dan Mixed. Yogyakarta: Pustaka Pelajar

Dokumen "Penataan Sempadan Sungai Bengawan Solo tahun 2012 studi kasus Kali Pepe dan Kali Anyar"

Dokumen "Penataan Kawasan Anak Sungai Bengawan Solo tahun 2014"

Fandeli, Chafid. 1995. Dasar-Dasar Manajemen Kepariwisataan Alam. Yogyakarta : Penerbit Liberty

Fandeli, C. dan Muhammad. 2009. Prinsipprinsip Dasar Mengkonservasi Lanskap. Yogyakarta : Gadjah Mada University Press

Peraturan Menteri Pekerjaan Umum tentang Pedoman Perencanaan, Penyediaan, dan Pemanfaatan Prasarana dan Sarana 
Jaringan Pejalan Kaki di Kawasan Perkotaan tahun 2014

Peraturan Pemerintah No. 37 Tahun 2012 tentang pengelolaan daerah aliran sungai

Peraturan Pemerintah Republik Indonesia Nomor 38 Tahun 2011 tentang sungai

Peraturan Pemerintah No 82 tahun 2001 pasal 8 tentang Pengelolaan Kualitas Air dan Pengendalian Pencemaran Air

Pitana, I.G. dan Diarta, I.K.S (2009) Pengantar Ilmu Pariwisata. Yogyakarta: Andi

Sevilla, Consuelo et,Al. 1993. Pengantar Metode Penelitian. Jakarta : Universitas Indonesia Press

SNI 03-1733-2004 tentang tata cara perencanaan lingkungan perumahan di perkotaan

Sunaryo. Bambang. 2013. Kebijakan Pembangunan Destinasi Pariwisata : Konsep dan aplikasinya di Indonesia.Yogyakarta: Gava Media

Undang-Undang No. 10 Tahun 2009 tentang Kepariwisataan

Yuliarsi, Agnes. 2005. Prioritas Pengembangan Obyek-Obyek Wisata Air Di Kawasan Rawa Pening Kabupaten Semarang. Semarang. Tugas Akhir. Jurusan Perencanaan Wilayah dan Kota. Fakultas Teknik, Universitas Diponegoro, Semarang 


\section{LAMPIRAN}

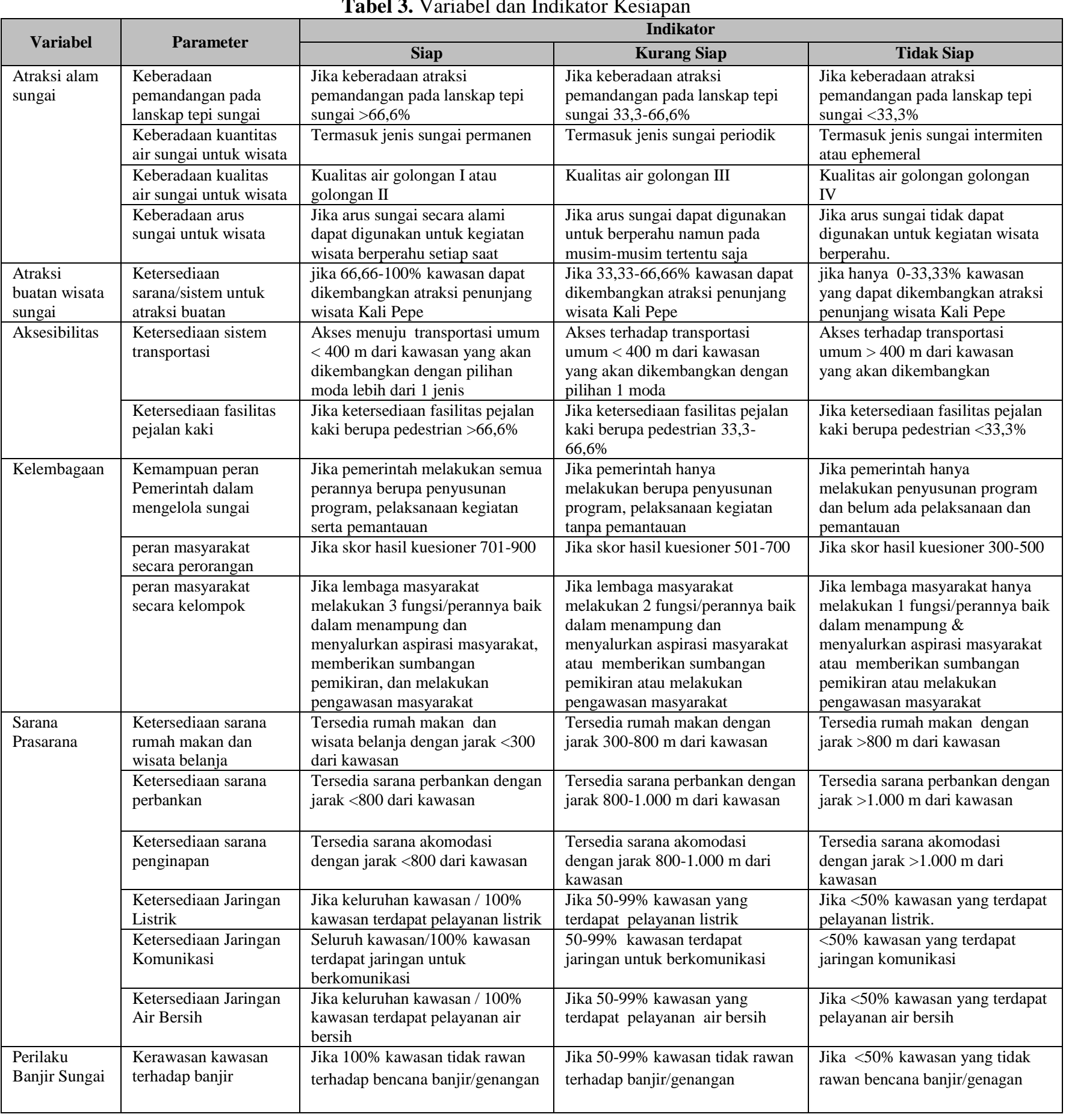

